\title{
Lactobacillus concavus sp. nov., isolated from the walls of a distilled spirit fermenting cellar in China
}

Correspondence

Xiuzhu Dong

dongxz@sun.im.ac.cn

\author{
Huichun Tong and Xiuzhu Dong
}

\author{
State Key Laboratory of Microbial Resources, Institute of Microbiology, Chinese Academy of \\ Sciences, Beijing 100080, P. R. China
}

\begin{abstract}
Two novel Lactobacillus strains, $\mathrm{C}-5-1^{\top}$ and HB5, were isolated from the walls of a distilled spirit fermenting cellar in Hebei province, China. The strains were Gram-positive, non-spore-forming, non-motile curved rods and were facultatively anaerobic. They produced $5 \%(-)-\mathrm{D} / 95 \%(+)-\mathrm{L}$ lactic acid exclusively from glucose fermentation, but were catalase-negative. Both strains fermented $N$-acetylglucosamine, arbutin, salicin, cellobiose, maltose, trehalose and $\beta$-gentiobiose. The mean DNA G $+C$ content of the two strains was $46 \cdot 9 \pm 0 \cdot 8 \mathrm{~mol} \%$ (46.4 mol\% for the type strain, $\mathrm{C}-5-1^{\top}$ ). Phylogenetic analysis based on $16 \mathrm{~S}$ rRNA gene sequence similarity showed that strain $\mathrm{C}-5-1^{\top}$ was clustered in the Lactobacillus caseilPediococcus phylogenetic group and was closely related to Pediococcus dextrinicus JCM $5887^{\top}$ ( $97 \cdot 9 \%$ similarity), followed by Lactobacillus algidus JCM $10491^{\top}$ ( $93.9 \%$ similarity). The DNA-DNA relatedness between the type strain C-5-1 $1^{\top}$ and $P$. dextrinicus $\mathrm{JCM} 5887^{\top}$ and $L$. algidus $\mathrm{JCM} 10491^{\top}$ was only 5.4 and $4.3 \%$, respectively. Therefore, based on phenotypic, genotypic and phylogenetic analyses, a novel Lactobacillus species, Lactobacillus concavus sp. nov., is proposed. The type strain is C-5-1 ${ }^{\top}\left(=\right.$ AS $1.5017^{\top}=$ LMG $\left.22739^{\top}\right)$.
\end{abstract}

Since the genus Lactobacillus was originally described by Beijerinck (Beijerinck, 1901; Skerman et al., 1980), nearly 120 species have been recognized. The lactobacilli are widely distributed in the environment and are frequently found in fermented food, vegetables and in the intestines of man and animals (Omar et al., 2000; Gardner et al., 2001; Satokari et al., 2003). Lactobacilli also play important roles in the wine-making process; they are responsible for malolactic fermentation, which follows alcoholic fermentation by yeasts (Lonvaud-Funel, 1999). In recent years, some novel lactic acid bacteria, such as Lactobacillus ferintoshensis (Simpson et al., 2001), Lactobacillus nagelii (Edwards et al., 2000), Lactobacillus amylolyticus (Bohak et al., 1998) and Pediococcus claussenii (Dobson et al., 2002), have been isolated from malt whisky, grape wine, beer malt and beer, respectively.

Chinese liquors are a type of wine produced through a solid fermentation of grain. During this process, grains of wheat or other cereals are mixed with water and sealed in a fermenting cellar for several months. The grains are fermented by the microorganisms present in the mud wall of the cellar. During an investigation of lactic acid bacteria in Chinese

Published online ahead of print on 10 June 2005 as DOI 10.1099/ ijs.0.63509-0.

Abbreviation: DAP, 2, 6-diaminopimelic acid.

The GenBank/EMBL/DDBJ accession number for the 16S rRNA gene sequence of Lactobacillus concavus sp. nov. AS $1.5017^{\top}$ is AY683322. wine breweries, we isolated two Lactobacillus strains from a brewery in Hebei province, China, which exhibited phenotypic characteristics that distinguished them from all the Lactobacillus species with validly published names. Phylogenetic analysis based on 16S rRNA gene sequence similarity and DNA-DNA hybridization indicated that the strains could represent a novel species of the genus Lactobacillus.

Lactobacillus algidus JCM $10491^{\mathrm{T}}$ (Kato et al., 2000) was provided by JCM (Japan Collection of Microorganisms). Strains C $-5-1^{\mathrm{T}}$ and HB5 were originally isolated from wall samples from a distilled spirit fermenting cellar in Hebei province, China. The samples were cultured anaerobically in MRS liquid (de Man et al., 1960) at $37^{\circ} \mathrm{C}$ for 2 days and then purified on MRS agar. The strains were routinely grown anaerobically on the same medium at $37^{\circ} \mathrm{C}$ unless otherwise stated. The end products of glucose fermentation in tryptone peptone yeast-extract glucose (TPYG) medium (Scardovi, 1986) were detected using a gas chromatograph (GC-14B; Shimadzu). Isomers of lactate formed from glucose were determined using a D-L-lactic acid test kit (Roche Diagnostics). Catalase activity was determined by adding $15 \%(\mathrm{v} / \mathrm{v})$ hydrogen peroxide to a fresh culture on a glass slide. The temperature profile was determined by using a water bath with a temperature gradient. Growth at various $\mathrm{pH}$ values was investigated using TPYG liquid medium adjusted with hydrochloric acid or $\mathrm{NaOH}$ solution. Tolerance to ethanol was measured by monitoring growth in TPYG liquid medium containing various concentrations $(\mathrm{v} / \mathrm{v})$ of 
Table 1. Differential phenotypic characteristics of Lactobacillus concavus $\mathrm{sp}$. nov. and phylogenetically related species

Species: 1, L. concavus C-5-1 ${ }^{\mathrm{T}}$; 2, L. concavus HB5; 3, L. algidus (data from Kato et al., 2000); 4, L. durianis (Leisner et al., 2002); 5, L. ferintoshensis (Simpson et al., 2001); 6, P. dextrinicus (Back, 1978). DNA G $+C$ content was determined by the temperature melting method unless otherwise indicated. The percentage of the $(+)$-L isomer of lactic acid present is indicated by DL, $40-60 \%$ (+)-L-lactic acid; L + DL, 60-80\% (+)-L-lactic acid; L, 80-100\% (+)-L-lactic acid. + , More than $90 \%$ of strains positive;,$-<10 \%$ of strains positive; $\mathrm{D}+, 50-89 \%$ of strains positive; $\mathrm{D}-, 11-49 \%$ of strains positive; $\mathrm{W}$, weak reaction; ND, not determined.

\begin{tabular}{|c|c|c|c|c|c|c|}
\hline Characteristic & 1 & 2 & 3 & 4 & 5 & 6 \\
\hline Cell morphology & Rod & Rod & Rod & Rod & Rod & Round \\
\hline Gas from gluconate & - & - & - & + & - & + \\
\hline \multicolumn{7}{|l|}{ Growth at: } \\
\hline $30{ }^{\circ} \mathrm{C}$ & + & + & - & + & + & + \\
\hline $45^{\circ} \mathrm{C}$ & - & - & - & - & - & - \\
\hline \multicolumn{7}{|l|}{ Acid production from: } \\
\hline Amygdalin & - & + & $\mathrm{D}^{-}$ & - & $\mathrm{ND}$ & + \\
\hline L-Arabinose & - & - & + & + & + & + \\
\hline D-Fructose & - & + & + & - & + & + \\
\hline Galactose & - & - & + & $\mathrm{D}+$ & + & + \\
\hline Gluconate & - & - & - & $\mathrm{W}$ & - & + \\
\hline D-Mannose & - & - & + & - & - & - \\
\hline Ribose & - & - & + & + & + & - \\
\hline $\mathrm{NH}_{3}$ from arginine & - & - & - & - & + & - \\
\hline Lactic acid isomer & $\mathrm{L}$ & $\mathrm{L}$ & $\mathrm{L}$ & $\mathrm{L}+\mathrm{DL}$ & DL & $\mathrm{L}$ \\
\hline DNA $G+C$ content & $46 \cdot 4$ & $47 \cdot 5$ & $36 \cdot 5^{\star}$ & $43 \cdot 2$ & ND & $40 \cdot 6$ \\
\hline$(\mathrm{mol} \%)$ & & & $37 \cdot 2 \dagger$ & & & \\
\hline
\end{tabular}

${ }^{\star}$ Determined by HPLC.

$\dagger$ This study.

ethanol. Generation time was measured by monitoring the $\mathrm{OD}_{600}$ of the MRS culture at $37^{\circ} \mathrm{C}$ for $72 \mathrm{~h}$. The sugar fermentation pattern was determined using the API $50 \mathrm{CH}$ system (bioMérieux) and $24 \mathrm{~h}$ incubation at $37^{\circ} \mathrm{C}$. The cellwall peptidoglycan was of the diaminopimelic acid (DAP) type as determined using a method modified from Becker et al. (1964). All of the tests were performed in duplicate.
Genomic DNA was extracted and purified using a modified method of Marmur (1961) and Dong et al. (2000). The 16S rRNA gene was amplified by PCR using genomic DNA as template. PCR products were sequenced by using a Dye terminator cycle sequencing ready reaction kit with an ABI PRISM 377XL DNA sequencer. The closest matching sequences were retrieved from the GenBank database and aligned. Similarity analysis was performed using the CLUSTAL_X program (Thompson et al., 1997). A phylogenetic tree was constructed using the neighbour-joining method (Saitou \& Nei, 1987) implemented in MEGA2 (Kumar et al., 2001). The stability of the tree was evaluated by bootstrap analysis of 1000 datasets. DNA G+C content was determined by the thermal denaturation method (Marmur \& Doty, 1962). DNA-DNA relatedness was determined on the basis of the DNA-DNA liquid hybridization rate (De Ley et al., 1970) at $63^{\circ} \mathrm{C}$ using a spectrophotometer with a thermal controller (DU-800; Beckman).

The two isolates were Gram-positive, non-spore-forming, non-motile curved rods. They had no catalase activity, were facultatively anaerobic and produced lactic acid exclusively [about $5 \%(-)$-D and $95 \%(+)$-L] without gas from glucose fermentation. The strains grew on acetate agar (pH 5.4) and did not produce $\mathrm{H}_{2} \mathrm{~S}$. These characters demonstrated that they were members of the genus Lactobacillus. By using the API $50 \mathrm{CH}$ system, the two novel strains were found to ferment only a few types of sugars (Table 1 and species description). Strains $C-5-1^{\mathrm{T}}$ and HB5 showed different reactions for the fermentation of $D$-fructose and amygdalin. The mean generation time of the two strains was $2 \cdot 3 \pm 0 \cdot 1 \mathrm{~h}$ when cultured anaerobically and $3 \cdot 6 \pm 0 \cdot 3 \mathrm{~h}$ when cultured aerobically. As expected from their habitat, the two strains were able to grow in concentrations of $8 \%(\mathrm{v} / \mathrm{v})$ ethanol.

The complete $16 \mathrm{~S}$ rRNA gene sequence of strain C-5-1 ${ }^{\mathrm{T}}$ was compared with the eight most similar sequences retrieved from GenBank. Six of these sequences were from members of genus Lactobacillus and the remaining two were from members of the genus Pediococcus. A phylogenetic tree (Fig. 1) rooted with Bacillus subtilis NCDO $1769^{\mathrm{T}}$ was constructed using the neighbour-joining method. Strain C-5- $1^{\mathrm{T}}$ was found to be clustered in the L. casei/Pediococcus

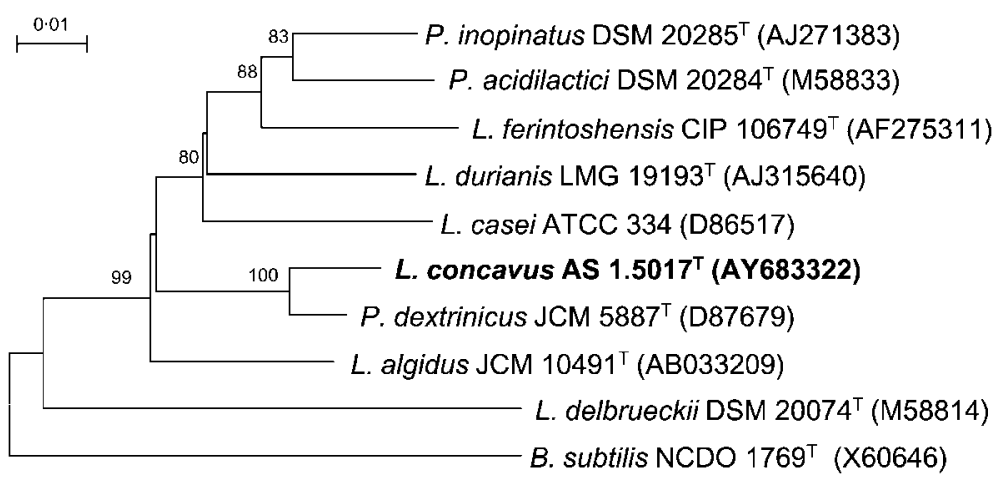

Fig. 1. Dendrogram based on $16 \mathrm{~S}$ rRNA gene sequence similarity of a consensus length of $1336 \mathrm{bp}$, indicating the phylogenetic relationship of Lactobacillus concavus $\mathrm{C}-5-1^{\top}$ and nine other bacterial species. The tree was rooted with Bacillus subtilis NCDO $1769^{\top}$ and constructed by using the neighbourjoining method with bootstrap values calculated from 1000 trees. The numbers at each branch point are the percentages supported by bootstrap. GenBank numbers are in parentheses. Bar, $1 \%$ sequence divergence. 
phylogenetic group (Collins et al., 1991) with 16S rRNA gene sequence similarity ranging from $87 \cdot 3$ to $97 \cdot 9 \%$. Strain C $-5-1^{\mathrm{T}}$ had the highest $16 \mathrm{~S}$ rRNA gene sequence similarity to Pediococcus dextrinicus JCM $5887^{\mathrm{T}}(97 \cdot 9 \%)$. The highest similarity to a Lactobacillus species, L. algidus JCM $10491^{\mathrm{T}}$, was only $93.9 \%$. The stability of the clustering in the tree (Fig. 1) was supported by high bootstrap values $(\geqslant 80 \%)$. Therefore, strain C-5-1 $1^{\mathrm{T}}$ may represent a novel Lactobacillus species belonging to the L. casei/Pediococcus phylogenetic group.

The mean DNA G $+\mathrm{C}$ content of the two novel strains was $46 \cdot 9 \pm 0 \cdot 8 \mathrm{~mol} \%\left(46 \cdot 4 \mathrm{~mol} \%\right.$ for the type strain C-5 $\left.-1^{\mathrm{T}}\right)$, which was within the range characteristic for the genus Lactobacillus (32-55 mol\%). However, this value was about $10 \mathrm{~mol} \%$ higher than that of its phylogenetically closest Lactobacillus species, L. algidus JCM $10491^{\mathrm{T}}$ (36 mol\%). It is generally agreed that organisms exhibiting a difference in DNA G $+\mathrm{C}$ content of more than $2 \mathrm{~mol} \%$ might be members of different species (Johnson, 1973). The DNA-DNA hybridization rate between strains $\mathrm{C}-5-1^{\mathrm{T}}$ and HB5 was determined to be $100 \%$, indicating that they formed a homogeneous genetic group. However, the DNA-DNA relatedness between strain C-5-1 ${ }^{\mathrm{T}}$ and the phylogenetically closest species, L. algidus JCM $10491^{\mathrm{T}}$ and $P$. dextrinicus JCM $5887^{\mathrm{T}}$, was $4 \cdot 3$ and $5 \cdot 4 \%$, respectively; much lower than the DNA-DNA relatedness threshold of $70 \%$ suggested to delineate a species.

Although strain C-5-1 $1^{\mathrm{T}}$ shared the highest $16 \mathrm{~S}$ rRNA gene sequence similarity to $P$. dextrinicus JCM $5887^{\mathrm{T}}(97 \cdot 9 \%)$, the following characteristics verified that the two novel strains constituted a separate species. Strain $\mathrm{C}-5-1^{\mathrm{T}}$ was a curved rod, while $P$. dextrinicus was spherical and occurred in tetrads. $P$. dextrinicus fermented D-fructose, amygdalin, galactose, D-mannose and gluconate (acid and gas) but strain $\mathrm{C}-5-1^{\mathrm{T}}$ did not (Table 1 ). Strain $\mathrm{C}-5-1^{\mathrm{T}}$ and $P$. dextrinicus showed low values of DNA-DNA relatedness and had a DNA G $+\mathrm{C}$ content which differed by about $6 \mathrm{~mol} \%$. The two novel strains could be easily differentiated from the closely related Lactobacillus species, $L$. algidus, a psychrophilic bacterium isolated from refrigerated beef, as they were able to grow above $30^{\circ} \mathrm{C}$, were unable to ferment ribose, galactose, L-arabinose or Dmannose and had a $10 \mathrm{~mol} \%$ difference in DNA G +C content (Table 1).

Collins et al. (1991) showed that $P$. dextrinicus formed a peripheral branch of the genus Pediococcus with low 16S rRNA gene sequence similarity $(92 \cdot 6-93 \%)$, but that it was intermixed in the $16 \mathrm{~S}$ rRNA phylogenetic tree with species of Lactobacillus with even higher $16 \mathrm{~S}$ rRNA gene sequence similarity $(92 \cdot 0-94 \cdot 8 \%)$. This implied that $P$. dextrinicus could be a specific lactic acid coccus and that its taxonomic position might need to be reconsidered taking into account its ability to ferment different substrates, such as dextrin and starch, when compared with other Pediococcus species. Recently, it has been found that bacterial cell shape is controlled by only a few genes, such as mreB and $f_{s t Z}$, and an alteration in cell shape can be induced by the inactivation of a single gene in this group (Jones et al., 2001). Hence, it may not be appropriate to use cell shape as a taxonomic marker in some groups of bacteria such as Lactobacillus and Pediococcus.

On the basis of a combination of phenotypic characteristics, phylogenetic relationships and DNA-DNA relatedness, a novel species of the genus Lactobacillus, Lactobacillus concavus sp. nov., is proposed.

\section{Description of Lactobacillus concavus sp. nov.}

Lactobacillus concavus (con.ca'vus. L. adj. concavus curved, referring to the curved shape of the strains).

Cells are Gram-positive, non-spore-forming, non-motile curved rods, about $0.5-0.6 \times 2 \cdot 0-2.5 \mu \mathrm{m}$ in size after $24 \mathrm{~h}$ incubation in anaerobic MRS liquid medium. Colonies are white, convex and smooth with an entire margin. Colonies are about $1 \mathrm{~mm}$ in diameter after $24 \mathrm{~h}$ cultivation on anaerobic MRS plates. Catalase-negative. Facultatively anaerobic. Lactic acid [about $5 \%(-)$-D and $95 \%(+)$-L], but no gas, is produced from glucose and gluconate fermentation. The diagnostic diamino acid in the cell-wall peptidoglycan is meso-DAP. The optimum temperature for growth is $30-37^{\circ} \mathrm{C}$; the temperature ranges for growth for $\mathrm{C}-5-1^{\mathrm{T}}$ and HB5 are $10-42^{\circ} \mathrm{C}$ and $10-39^{\circ} \mathrm{C}$, respectively. Optimum pH is $6 \cdot 0-6 \cdot 4$; the $\mathrm{pH}$ ranges for growth of $\mathrm{C}-5-1^{\mathrm{T}}$ and HB5 are $3 \cdot 8-8 \cdot 1$ and $4 \cdot 3-8 \cdot 1$, respectively. Growth can occur in $8 \%(\mathrm{v} / \mathrm{v})$ ethanol, but not in $6 \cdot 5 \%(\mathrm{w} / \mathrm{v}) \mathrm{NaCl}$. Aesculin is hydrolysed but arginine is not hydrolysed. VogesProskauer test is negative. Acid is produced from D-glucose, $\mathrm{N}$-acetylglucosamine, arbutin, salicin, cellobiose, maltose, trehalose and $\beta$-gentiobiose. Acid is not produced from glycerol, erythritol, D-arabinose, L-arabinose, ribose, Dxylose, L-xylose, adonitol, methyl $\beta$-xyloside, galactose, Dmannose, L-sorbose, rhamnose, dulcitol, inositol, mannitol, sorbitol, methyl $\alpha$-D-mannoside, methyl $\alpha$-D-glucoside, lactose, melibiose, sucrose, inulin, melezitose, D-raffinose, starch, glycogen, xylitol, D-turanose, D-lyxose, D-tagatose, D-fucose, L-fucose, D-arabitol, L-arabitol, gluconate, 2ketogluconate or 5-ketogluconate. Fermentation of Dfructose and amygdalin is variable. The DNA G $+\mathrm{C}$ content is $46 \cdot 9 \pm 0 \cdot 8 \mathrm{~mol} \%\left(46 \cdot 4 \mathrm{~mol} \%\right.$ for the type strain, $\left.\mathrm{C}-5-1^{\mathrm{T}}\right)$.

The type strain, $\mathrm{C}-5-1^{\mathrm{T}}\left(=\right.$ AS $\left.1.5017^{\mathrm{T}}=\mathrm{LMG} 22739^{\mathrm{T}}\right)$, was isolated from the walls of a distilled spirit fermenting cellar in Hebei province, China.

\section{Acknowledgements}

This study was supported by a grant from the National Natural Science Foundation of China under no. 30230020.

\section{References}

Back, W. (1978). Elevation of Pediococcus cerevisiae subsp. dextrinicus Coster and White to species status [Pediococcus dextrinicus (Coster and White) comb. nov.]. Int J Syst Bacteriol 28, 523-527. 
Becker, B., Lechevalier, M. P., Gordon, R. E. \& Lechevalier, H. A. (1964). Rapid differentiation between Nocardia and Streptomyces by paper chromatography of whole-cell hydrolysates. Appl Microbiol 12, 421-423.

Beijerinck, M. W. (1901). Sur les ferments lactiques de l'industrie. Arch Neerl Sci Exactes Nat 6, 212-243 (in French).

Bohak, I., Back, W., Richter, L., Ehrmann, M., Ludwig, W. \& Schleifer, K. H. (1998). Lactobacillus amylolyticus sp. nov., isolated from beer malt and beer wort. Syst Appl Microbiol 21, 360-364.

Collins, M. D., Rodrigues, U., Ash, C., Aguirre, M., Farrow, J. A. E., Martinez-Murcia, A., Philips, B. A., Williams, A. M. \& Wallbanks, S. (1991). Phylogenetic analysis of the genus Lactobacillus and related lactic acid bacteria as determined by reverse transcriptase sequencing of 16S rRNA. FEMS Microbiol Lett 77, 5-12.

De Ley, J., Cattoir, H. \& Reynaerts, A. (1970). The quantitative measurement of DNA hybridization from renaturation rates. Eur I Biochem 12, 133-142.

De Man, J. C., Rogosa, M. \& Sharpe, M. E. (1960). A medium for the cultivation of lactobacilli. J Appl Bacteriol 23, 130-135.

Dobson, C. M., Deneer, H., Lee, S., Hemmingsen, S., Glaze, S. \& Ziola, B. (2002). Phylogenetic analysis of the genus Pediococcus, including Pediococcus claussenii sp. nov., a novel lactic acid bacterium isolated from beer. Int J Syst Evol Microbiol 52, 2003-2010.

Dong, X., Xin, Y., Jian, W., Liu, X. \& Ling, D. (2000). Bifidobacterium thermacidophilum sp. nov., isolated from an anaerobic digester. Int J Syst Evol Microbiol 50, 119-125.

Edwards, C. G., Collins, M. D., Lawson, P. A. \& Rodriguez, A. V. (2000). Lactobacillus nagelii sp. nov., an organism isolated from a partially fermented wine. Int J Syst Evol Microbiol 50, 699-702.

Gardner, N. J., Savard, T., Obermeier, P., Caldwell, G. \& Champagne, C. P. (2001). Selection and characterization of mixed starter cultures for lactic acid fermentation of carrot, cabbage, beet and onion vegetable mixtures. Int J Food Microbiol 20, 261-275.

Johnson, J. L. (1973). Use of nucleic acid homologies in the taxonomy of anaerobic bacteria. Int J Syst Bacteriol 23, 308-315.

Jones, L. J., Carballido-Lopez, R. \& Errington, J. (2001). Control of cell shape in bacteria: helical, actin-like filaments in Bacillus subtilis. Cell 104, 913-922.

Kato, Y., Sakala, R. M., Hayashidani, H., Kiuchi, A., Kaneuchi, C. \& Ogawa, M. (2000). Lactobacillus algidus sp. nov., a psychrophilic lactic acid bacterium isolated from vacuum-packaged refrigerated beef. Int J Syst Evol Microbiol 50, 1143-1149.

Kumar, S., Tamura, K., Jakobsen, I. B. \& Nei, M. (2001). MEGA2: molecular evolutionary genetics analysis software. Bioinformatics $\mathbf{1 7}$, $1244-1245$.

Leisner, J. J., Vancanneyt, M., Lefebvre, K., Vandemeulebroecke, K., Hoste, B., Vilalta, N. E., Rusul, G. \& Swings, J. (2002). Lactobacillus durianis sp. nov., isolated from an acid-fermented condiment (tempoyak) in Malaysia. Int J Syst Evol Microbiol 52, 927-931.

Lonvaud-Funel, A. (1999). Lactic acid bacteria in the quality improvement and depreciation of wine. Antonie van Leeuwenhoek 76, 317-331.

Marmur, J. (1961). A procedure for the isolation of deoxyribonucleic acid from microorganisms. J Mol Biol 3, 208-218.

Marmur, J. \& Doty, P. (1962). Determination of the base composition of deoxyribonucleic acid from its thermal denaturation temperature. J Mol Biol 5, 109-118.

Omar, N. B., Ampe, F., Raimbault, M., Guyot, J. P. \& Tailliez, P. (2000). Molecular diversity of lactic acid bacteria from cassava sour starch (Colombia). Syst Appl Microbiol 23, 285-291.

Saitou, N. \& Nei, M. (1987). The neighbor-joining method: a new method for reconstructing phylogenetic trees. Mol Biol Evol 4, 406-425.

Satokari, R. M., Vaughan, E. E., Smidt, H., Saarela, M., Matto, J. \& de Vos, W. M. (2003). Molecular approaches for the detection and identification of bifidobacteria and lactobacilli in the human gastrointestinal tract. Syst Appl Microbiol 26, 572-584.

Scardovi, V. (1986). Genus Bifidobacterium Orla-Jensen. In Bergey's Manual of Systematic Bacteriology, vol. 2, pp. 1418-1434. Edited by P. H. A. Sneath, N. S. Mair, M. E. Sharpe \& J. G. Holt. Baltimore: Williams \& Wilkins.

Simpson, K. L., Pettersson, B. \& Priest, F. G. (2001). Characterization of lactobacilli from Scotch malt whisky distilleries and description of Lactobacillus ferintoshensis sp. nov., a new species isolated from malt whisky fermentations. Microbiology 147, 1007-1016.

Skerman, V. B. D., McGowan, V. \& Sneath, P. H. A. (1980). Approved lists of bacterial names. Int J Syst Bacteriol 30, 225-420.

Thompson, J. D., Gibson, T. J., Plewniak, F., Jeanmougin, F. \& Higgins, D. G. (1997). The CLUSTAL_X windows interface: flexible strategies for multiple sequence alignment aided by quality analysis tools. Nucleic Acids Res 25, 4876-4882. 